\title{
Antibacterial and cytotoxic properties of some plant crude extracts used in Northeastern folk medicine
}

\author{
Suzana C. S. Ramos, ${ }^{1}$ José C. S. de Oliveira, ${ }^{2}$ Cláudio A. G. da Câmara, ${ }^{2}$ Ivan Castelar, ${ }^{3}$ \\ Ana F. F. U. Carvalho, ${ }^{4}$ José V. Lima-Filho ${ }^{*, 1}$
}

${ }^{1}$ Laboratório de Microbiologia e Imunologia, Departamento de Biologia, Universidade Federal Rural de Pernambuco, Campus Dois Irmãos, 52171-900 Recife-PE, Brazil,

${ }^{2}$ Laboratório de Produtos Naturais Bioativos, Departamento de Química, Universidade Federal Rural de Pernambuco, Campus Dois Irmãos, 52171-900 Recife-PE, Brazil,

${ }^{3}$ Departamento de Economia Aplicada, Universidade Federal do Ceará, Campus Benfica, Av.da Universidade 2700, 60020-181 Fortaleza-CE, Brazil,

${ }^{4}$ Laboratório de Fisiologia Animal, Departamento de Biologia, Universidade Federal do Ceará, Campus do Pici, Av. Humberto Monte s/n, 60455-760 Fortaleza-CE, Brazil

\begin{abstract}
RESUMO: "Propriedades antibacterianas e citotóxicas de alguns extratos de plantas usados na medicina popular nordestina". No presente estudo, 32 extratos hexânicos e etanólicos de Protium bahianum, P. heptaphyllum, Croton sellowii, C. rhamnifolius, C. jacobinensis, C. micans e Muntingia calabura, foram avaliados para atividade antibacteriana, pelo método de difusão em disco. Ensaios de citoxicidade foram realizados com o modelo do microcrustáceo Artemia salina Leach para determinar a concentração letal para 50\% dos indivíduos $\left(\mathrm{CL}_{50} \mu \mathrm{g} / \mathrm{mL}\right)$. A presença de atividade antibacteriana foi observada com os extratos hexânicos das flores de M. calabura contra B. subtilis, e extratos etanólicos das folhas contra $S$. aureus and B. subtilis na concentração de 1 $\mathrm{mg} / \mathrm{mL}$. Dentre os 32 extratos, 19 apresentaram toxicidade baixa ou ausente $\left(\mathrm{CL}_{50}>250 \mu \mathrm{g} / \mathrm{mL}\right)$, 6 mostraram toxicidade moderada $\left(\mathrm{CL}_{50}\right.$ entre $80 \mu \mathrm{g} / \mathrm{mL}$ e $\left.250 \mu \mathrm{g} / \mathrm{mL}\right)$ e 7 foram muito tóxicos $\left(\mathrm{CL}_{50}<80 \mu \mathrm{g} / \mathrm{mL}\right)$.
\end{abstract}

Unitermos: Artemia salina, citotoxicidade, atividade antibacteriana, Croton, Protium, Muntingia calabura.

\begin{abstract}
In the present study, 32 hexane and ethanol extracts of Protium bahianum, P. heptaphyllum, Croton sellowii, C. rhamnifolius, C. jacobinensis, C. micans and Muntingia calabura were screened for antibacterial activity by the disc-diffusion method. Cytotoxicity assays using the brine shrimp Artemia salina Leach as a model were performed to determine lethal doses for $50 \%$ of individuals $\left(\mathrm{LC}_{50} \mu \mathrm{g} / \mathrm{mL}\right)$. Antibacterial activity was found in flowers hexane extracts of $M$. calabura against B. subtilis, and leaves ethanol extracts against $S$. aureus and B. subtilis at concentration of $1 \mathrm{mg} / \mathrm{mL}$. Among 32 extracts, 19 showed low or no toxicity $\left(\mathrm{LC}_{50}>250 \mu \mathrm{g} / \mathrm{mL}\right), 6$ showed moderate toxicity ( $\mathrm{LC}_{50}$ between $80 \mu \mathrm{g} / \mathrm{mL}$ and $\left.250 \mu \mathrm{g} / \mathrm{mL}\right)$, and 7 were highly toxic $\left(\mathrm{LC}_{50}\right.$ $<80 \mu \mathrm{g} / \mathrm{mL})$.
\end{abstract}

Keywords: Artemia salina, cytotoxicity, antibacterial activity, Croton, Protium, Muntingia calabura.

\section{INTRODUCTION}

Brazilian flora is worldwide known to be a source of chemical substances with biological activity (Barbosa-Filho et al., 2007; Corrêa et al., 2008; Sousa et al., 2008). Plant crude extracts have been used in folk medicine for treatment of abscesses, insect bite, mycosis, genital infections, anti-inflammatory, antihelminthic, diarrhea and cough (Nakamura et al., 1999; LealCardoso et al., 1999; Holetz et al., 2002). This potential has been exploited by the pharmacological industry on the production of new analgesic, anticarcinogenic and antimicrobial drugs (Bruneton, 1999). The search for new antimicrobial compounds is particularly motivated by the great diversity of Brazilian plant species whose biological activities are not completely known (Alves et al., 2000; Cardoso-Lopes et al., 2008).

Plant extracts and essential oils have been broadly reported to inhibit growth of both fungi and bacteria (Adam et al., 1998; Bara; Vanetti., 1998; Nascimento, 2000; Volpato et al., 2001; Vieira et al., 2001; Holetz et al., 2002; Loguercio et al., 2005; Costa 
et al., 2008). For example, Suffredini et al (2004) have shown among 705 organic and aqueous extracts of plants obtained from Amazon Rain Forest and Atlantic Forest, many were active against Staphylococcus aureus, Enterococcus faecalis, Pseudomonas aeruginosa and Escherichia coli. As well, antibacterial and antifungal activities against pathogenic microorganisms of human medical importance such as Staphylococcus aureus, Streptococcus sobrinus, Porphyromonas gingivalis, Streptococcus mutans, Candida albicans and Cryptococcus neoformans were recently described for essential oil of Croton species (Alviano et al., 2005; Fontenelle et al., 2008). Similar studies have lead to identification of antimicrobial compounds in Croton species, such as hardwickic and 3,4-secotrachylobanoic acids, linalool, alpha-phellandrene, alpha-pinene and p-cymene (McChesney et al. 1991; Martins et al. 2000; Alviano et al. 2005).

The genus Croton (Euphorbiaceae) comprises about 1,000 species widespread in the Northeastern Region of Brazil with many species used in folk medicine for treatment of inflammations, wound infections, hypertension, ulcers, cancer, rheumatism and malaria (Marini-Bettolo; Scarpati, 1979; Burke et al., 1981; Peres et al., 1997; Bighetti et al., 1999; Hiruma-Lima et al., 2002; Agra et al., 2007; 2008). Likewise, genus Protium (Burseraceae) has a broad range use in folk medicine as tonic, stimulant, anti-inflammatory, and analgesic, for treatment of cough, ulcer and hemorrhages (Costa, 1975; Correa, 1978; Pott \& Pott, 1994; Siani et al., 1999; Brandão et al., 2008). Moreover, flowers of $M$. calabura have been used as anti-septic, anti-spasmodic, antidyspeptic, diaphoretic, tranquilizer, tonic and for the treatment of headache, whereas roots are employed as emmenagogue and abortifacient (Correa, 1978; Kaneda et al., 1991).

Considering in vitro tests are the first step on elucidation of biological properties of plant crude extracts and for selection of substances of pharmacological interest, in the present study we evaluated 32 plant extracts of Croton and Protium species, and also M. calabura, ordinarily used in the Northeastern folk medicine.

\section{MATERIAL AND METHODS}

\section{Plant material}

Table 1 shows the plant species used in this study. The botanical identification was provided by $\mathrm{Dr}$ Carmen Zickel from the Universidade Federal Rural de Pernambuco (UFRPE). Each plant species received a voucher number and was deposited in the Vasconcelos Sobrinho Herbarium at the Biology Department.

\section{Obtaining plant extracts}

The methodology used was adapted from Matos (1988). Leaves and stem of Croton and Protium species, and flowers, fruits, leaves and stem of Muntingia calabura were selected and dried in oven at $45{ }^{\circ} \mathrm{C}$. Dried parts were ground to a fine powder and submitted to successive extractions with hexane or ethanol during $24 \mathrm{~h}$. Then, the solvents were evaporated at reduced pressure and the extracts were weighed and suspended in chloroform to obtain a stock solution of $50 \mathrm{mg} / \mathrm{mL}$ $(w / v)$.

\section{Microbial strains}

The gram-negative bacterial strains Escherichia coli, Salmonella enterica Subsp. enterica Var. Typhi (ATCC - 6534) and Pseudomonas aeruginosa (ATCC - 27853) and Gram-positive Staphylococcus aureus (ATCC - 6538) and Bacillus subtilis (ATCC - 6633) were used as test organisms. All bacteria were grown in Nutrient broth at $37^{\circ} \mathrm{C}$ and maintained in Nutritive agar at $4 \mathrm{C}$ until use.

\section{Antibacterial tests}

Antibacterial tests were carried out by the disc diffusion method (Bauer et al., 1966). Briefly, bacterial strains were grown in Brain Heart Infusion broth (Oxoide) for $24 \mathrm{~h}$ at $37^{\circ} \mathrm{C}$. Cultures were adjusted to $10^{8}$ $\mathrm{ml}^{-1}$ cells ( 0.5 of the MacFarland Standard) and added to Petri dishes containing Müeller Hinton agar (Oxoide) using a sterile swab. Sterile filter paper disks, $6 \mathrm{~mm}$ in diameter, were embedded with $20 \mu \mathrm{L}$ of plant extracts (corresponding to $1 \mathrm{mg}$ from extract stock solution) and added onto plates. Before incubation, Petri dishes were left at room temperature for $30 \mathrm{~min}$ to facilitate diffusion of extracts on medium. All assays were carried out in duplicate. Discs with $20 \mu \mathrm{L}$ chloroform were used as control. Diameter inhibition zone was measured in millimeters, using a a caliper, after $18 \mathrm{~h}$ incubation at 37 ${ }^{\circ} \mathrm{C}$. In all experiments a diameter zone inhibition of 10 $\mathrm{mm}$ or smaller was not considered.

\section{Cytotoxicity assay}

Citotoxicity evaluation of plant extracts was carried out using the brine shrimp Artemia salina Leach as model (Carvalho et al., 1988; Meyer et al., 1982; Silva et al., 2007; Nunes et al., 2008). Eggs of A. salina were incubated in Marine Salt solution (2.5\%) and exposed to a lamp of $45 \mathrm{~W}$ by three days for egg's hatching. Then, metanauplii were collected and transferred to tubes containing $5 \mathrm{~mL}$ Marine Salt solution 2.5\% (10 nauplii/ tube) containing plant extracts in several concentrations $(25,50,75,100,150,200$ e $250 \mu \mathrm{g} / \mathrm{mL})$ plus $1 \%$ DMSO (dimethyl-sulfoxide). Tubes were incubated in a dark 
Table 1. Plants selected for antimicrobial and toxicity evaluation.

\begin{tabular}{|c|c|c|c|c|}
\hline $\begin{array}{l}\text { Scientific name } \\
\text { (Voucher number) }\end{array}$ & Popular name & Family & Popular use & Part tested \\
\hline Protium bahianum Daly (46380) & Breu/Almécega & Burseraceae & Analgesic & Leaves, stem \\
\hline Protium heptaphyllum March. (46329) & Almécega & Burseraceae & Antioxidant & Leaves, stem \\
\hline Croton sellowii Baill (45622) & Marmeleiro & Euphorbiaceae & Anti-inflammatory & Leaves, stem \\
\hline Croton rhamnifolius Kunth. (45552) & Velame & Euphorbiaceae & Ulcer treatment & Leaves, stem \\
\hline Croton jacobinensis Baill (45553) & Marmeleiro branco & Euphorbiaceae & Anti-hypertensive & Leaves, stem \\
\hline Croton micans Sw. (45553) & Umbuzeiro & Euphorbiaceae & Diarrhoea control & Leaves, stem \\
\hline Muntingia calabura L. (2816) & Pau de Seda & Muntingiaceae & Antispasmodic & $\begin{array}{l}\text { Flower, fruit, } \\
\text { leaves, stem }\end{array}$ \\
\hline
\end{tabular}

*References included in the text.

room at $28^{\circ} \mathrm{C}$ and $A$. salina survival was observed $24 \mathrm{~h}$ later. Control tubes with $1 \%$ DMSO did not contain plant extracts. Experiments were carried out in triplicates.

Toxicity was measured in terms of $\mathrm{LC}_{50}$ (lethal concentration for $50 \%$ of metanauplii) and according to Dolabela (1997): $\mathrm{LC}_{50}<80 \mu \mathrm{g} / \mathrm{mL}$, was considered highly toxic; between $80 \mu \mathrm{g} / \mathrm{mL}$ and $250 \mu \mathrm{g} / \mathrm{mL}$, moderately toxic; $\mathrm{LC}_{50}>250 \mu \mathrm{g} / \mathrm{mL}$, low toxicity or non toxic. Extracts that have not show 50\% mortality in any of the tested concentration were considered non toxic.

\section{Statistical analysis}

Lethal doses of the plant extracts were determined using $\mathrm{LC}_{50}$ software program of E-Views version 4.1, based on Finney's Probit Analysis Statistical method (Finney, 1971).

\section{RESULTS AND DISCUSSION}

Our data have shown Croton and Protium extracts did not carry inhibitory activity against the tested bacteria at concentration of $1 \mathrm{mg}$ per disc. This high tested concentration was useful considering that bioactive compounds in plant extracts are present at distinct proportions. Although a small inhibitory halo (smaller than $10 \mathrm{~mm}$ in diameter) was observed by some Croton and Protium species against the B. subtilis and $S$. aureus (data not shown), it was not considered for further data analyses. On the other hand, a growth inhibition zone was measured in flowers hexane extracts of $M$. calabura against $B$. subtilis $(11.0 \mathrm{~mm} \pm 0.5)$, and leaves ethanol extracts against $S$. aureus $(13.0 \mathrm{~mm} \pm$ $0.5)$ and B. subtilis $(11.0 \mathrm{~mm} \pm 0.5)$. Although it was not the aim of the present study to evaluate the effect of extracts against yeasts, we have found flower hexane extracts of M. calabura also inhibited in vitro growth of Candida albicans $(19.5 \mathrm{~mm} \pm 0.5)$ and Cryptococcus neoformans (12.5 $\mathrm{mm} \pm 0.5)$.

The lack of antimicrobial activity in the Croton and Protium species evaluated here could be attributed to the presence of distinct compounds present at different amounts in plant extracts. For example, Palmeira et al.
(2003) have shown caryophyllene oxide (46.8\%) and trans-caryophyllene $(40.8 \%)$ were the most abundant compound in the leaves, whereas caryophyllene oxide $(26.5 \%)$ and cubenol $(16.7 \%)$ were the main constituents in the stems of C. sellowii. On the other hand, antimicrobial activity for Croton species have been previously reported for C. nepetaefolius containing methyl-eugenol (15.7\%) and bicyclogermacrene (14.1\%) as main constituents, and C. argyrophylloides containing spathulenol (20.3\%) and bicyclogermacrene (11.7\%) (Fontenelle et al., 2008). Thus, antimicrobial activity in plant species depends on part of the plant studied as well as on solvent used for the extraction procedures.

Cytotoxicity assays revealed nineteen extracts have shown low or no toxicity $\left(\mathrm{LC}_{50}>250 \mu \mathrm{g} / \mathrm{L}\right)$ whereas thirteen showed toxicity ranging from moderate $\left(\mathrm{LC}_{50}\right.$ between 80 and $\left.250 \mu \mathrm{g} / \mathrm{L}\right)$ to highly toxic $\left(\mathrm{LC}_{50}<\right.$ $80 \mu \mathrm{g} / \mathrm{L})$. The $\mathrm{LC}_{50}$ for each extract are shown in table 2. There was a high toxicity in stem ethanol extracts of C. jacobinensis and C. rhamnifolius. Stem hexane and ethanol extracts and leaves ethanol extract from $C$. selowii were also highly toxic as well as flowers and leaves hexane extract of M. calabura (Table 2). Croton rhamnifolius (leaves and stem hexane extracts) and C. micans (leaves ethanol and stem hexane extracts) showed moderate toxicity whereas Protium bahianum (leaves ethanol extract), C. jacobinensis (stem hexane extract) and C. micans (leaves hexane extract) showed low toxicity. P. heptaphyllum and all the other extracts have shown low or no toxicity regardless of the concentrations tested.

The brine shrimp Artemia salina Leach is a useful tool for toxicity evaluation of plant extracts (Carvalho et al., 1988; Alves et al., 2000). This in vitro model has a good correlation between tests using mice (Logarto et al., 2001). Among 32 plant extracts tested in this study, extracts from Croton species were the most toxic (Table 2). Toxicity in some Croton species was reported and seems to be due to the presence of diterpenoids (Rodriguez et al., 2004; Giang et al., 2005). Toxicity was not limited to a specific anatomic part of the plant or a particular secondary metabolite. On the other hand, Muntingia calabura toxicity to A. 
Table 2. Toxicity of plant extracts against nauplii of Artemia salina Leach.

\begin{tabular}{|c|c|c|c|}
\hline Plant species & Extract & $\begin{array}{c}\mathrm{LC}_{50} \\
\mu \mathrm{g} / \mathrm{mL}\end{array}$ & Toxicity classification \\
\hline \multirow[t]{4}{*}{ Protium bahianum } & Leaves hexane & $>250$ & $\mathrm{NT}^{*}$ or low \\
\hline & Leaves ethanol & 282.36 & NT or low \\
\hline & Stem hexane & $>250$ & NT or low \\
\hline & Stem ethanol & $>250$ & NT or low \\
\hline \multirow[t]{4}{*}{ Protium heptaphyllum } & Leaves hexane & $>250$ & NT or low \\
\hline & Leaves ethanol & $>250$ & NT or low \\
\hline & Stem hexane & $>250$ & NT or low \\
\hline & Stem ethanol & $>250$ & NT or low \\
\hline \multirow[t]{4}{*}{ Croton sellowii } & Leaves hexane & $>250$ & NT or low \\
\hline & Leaves ethanol & 32.28 & High \\
\hline & Stem hexane & 31.25 & High \\
\hline & Stem ethanol & 53.84 & High \\
\hline \multirow[t]{4}{*}{ Croton rhamnifolius } & Leaves hexane & 215.47 & Moderate \\
\hline & Leaves ethanol & $>250$ & NT or low \\
\hline & Stem hexane & 148.32 & Moderate \\
\hline & Stem ethanol & 0.15 & High \\
\hline \multirow{4}{*}{ Croton jacobinensis } & Leaves hexane & $>250$ & NT or low \\
\hline & Leaves ethanol & $>250$ & NT or low \\
\hline & Stem hexane & 322.97 & NT or low \\
\hline & Stem ethanol & 6.37 & High \\
\hline \multirow[t]{4}{*}{ Croton micans } & Leaves hexane & 333.71 & NT or low \\
\hline & Leaves ethanol & 203.78 & Moderate \\
\hline & Stem hexane & 238,27 & Moderate \\
\hline & Stem ethanol & $>250$ & NT or low \\
\hline \multirow[t]{8}{*}{ Muntingia calabura } & Flowers hexane & 41.2 & High \\
\hline & Flowers ethanol & 244.5 & Moderate \\
\hline & Fruits hexane & $>250$ & NT or low \\
\hline & Fruits ethanol & 169.96 & Moderate \\
\hline & Leaves hexane & 66.44 & High \\
\hline & Leaves ethanol & $>250$ & NT or low \\
\hline & Stem hexane & $>250$ & NT or low \\
\hline & Stem ethanol & $>250$ & NT or low \\
\hline
\end{tabular}

$* \mathrm{NT}=$ non toxic

salina varied from low to high, depending on the part of the plant used in assay. Previously, Kaneda et al. (1991) reported cytotoxicity to cultured P-388 cells and some human cancer cell lines for M. calabura flavonoids.

Taken together, our data revealed flower hexane extracts of $M$. calabura seem to correlate in cytotoxicity and antimicrobial activity against $B$. subtilis. On the other hand, leaves ethanol extracts of $M$. calabura were not toxic, but inhibited in vitro growth of S. aureus and B. subtilis as well. However, at the present we cannot indicate the significance of such data; this work highlights the potential of $M$. calabura for new pharmacological studies.

\section{CONCLUSION}

In the present work, we reported new data about the antibacterial activity and toxicity of plant extracts not reported before. The results here are a starting point for new studies concerning the knowledge of the biological activities of plants from Northeastern Brazil.

\section{REFERENCES}

Adam K, Kokkini S, Lanaras T, Sivropoulou A, Arsenakis M 1998. Antifungal activities of Origanum vulgare subsp. hirtum, Mentha spicata, Lavandula angustifolia and Salvia fruticosa essential oils against humam pathogenic fungi. J Agric Food Chem 46: 1739-1745.

Agra MF, França PF, Barbosa-Filho JM 2007. Synopsis of the plants known as medicinal and poisonous in Northeast of Brazil. Rev Bras Farmacogn 17: 114-140.

Agra MF, Silva KN, Basílio IJLD, França PF, Barbosa-Filho JM 2008. Survey of medicinal plants used in the region Northeast of Brazil. Rev Bras Farmacogn 18: 472508.

Alves TMA, Silva AF, Brandão M, Grandi TSM 2000. Biological screnning of Brazilian medicinal plants. Mem Inst Oswaldo Cruz 95: 367-373.

Alviano WS, Mendonça-Filho RR, Alviano DS, Bizzo HR, Souto-Padro'n T, Rodrigues ML, Bolognese AM, Alviano CS, Souza MMG 2005. Antimicrobial activity of Croton cajucara Benth linalool-rich essential oil on artificial biofilms and planktonic microorganisms. 
Oral Microbiol Immunol 20: 101-105.

Bara MTF, Vanetti MCD 1998. Estudo da atividade antibacteriana de plantas medicinais, aromáticas e corantes naturais. Rev Bras Farmacogn 7/8: 21-34.

Barbosa-Filho JM, Nascimento-Júnior FA, Tomaz ACA, Athayde-Filho PF, Silva MS, Cunha EVL, Souza MFV, Batista LM, Diniz MFFM 2007. Natural products with antileprotic activity. Rev Bras Farmacogn 17: 141148.

Bauer AW, Kirby WMW, Shenhis IC, Turck M 1966. Antibiotic susceptibility testing by a standartized single disc method. Am J Clin 45: 493.

Bighetti EJ, Hiruma-Lima CA, Gracioso JS, Brito AR 1999. Anti-inflammatory and antinociceptive effects in rodents of the essential oil of Croton cajucara Benth. J Pharm Pharmacol 51: 1447-53.

Brandão MGL, Zanetti NNS, Oliveira GRR, Goulart LO, MonteMor RLM 2008. Other medicinal plants and botanical products from the first edition of the Brazilian Official Pharmacopoeia. Rev Bras Farmacogn 18: 127-134.

Bruneton J 1999. Pharmacognosy, phytochemistry, medicinal plants. Intercept Ltd.: London, Paris, New York, 2 ed.

Burke BA, Chan WR, Pascoe RO, Blont JF, Manchand PS 1981. The structure of crotonitenone: a novel casbane diterpene from Croton nitens Sw (Euphorbiaceae). $J$ Chem Soc Perkin I: 2666-2669.

Cardoso-Lopes EM, Carreira RC, Agripino DG, Torres LMB, Cordeiro I, Bolzani VS, Dietrich SMC, Young MCM 2008. Screening for antifungal, DNA-damaging and anticholinesterasic activities of Brazilian plants from the Atlantic Rainforest - Ilha do Cardoso State Park. Rev Bras Farmacogn 18 (Supl.): 655-660.

Carvalho AFFU, Melo VMM, Aguiar LMBA, Matos FJA 1988. Avaliação da toxicidade de extratos de plantas medicinais através de bioensaio com Artemia salina Leach. Cienc Cult 40: 1109-1111.

Correa MP 1978. Dicionário das plantas úteis do Brasil e das exóticas cultivadas. Imprensa nacional, Rio de janeiro, v.III.

Corrêa MFP, Melo GO, Costa SS 2008. Substâncias de origem vegetal potencialmente úteis na terapia da Asma. Rev Bras Farmacogn 18 (Supl.): 785-797.

Costa AF 1975. Farmacognosia, $4^{\mathrm{a}}$ ed., Fundação Calouste gulbenkian, Lisboa-Portugal, 841-842.

Costa VCO, Tavares JF, Agra MF, Falcão-Silva VS, Facanali R, Vieira MAR, Marques MOM, Siqueira-Júnior JP, Silva MS 2008. Composição química e modulação da resistência bacteriana a drogas do óleo essencial das folhas de Rollinia leptopetala R. E. Fries. Rev Bras Farmacogn 18: 245-248.

Dolabela MF 1997. Triagem in vitro para atividade antitumoral e anti-Tripanossoma cruzi de extratos vegetais, produtos naturais e substancias sintéticas. Dissertação de Mestrado -UFMG, Belo Horizonte, 128p.

Finney D 1971. Em probit analisis; $3^{\text {a }}$ ed., Cambridge University Press: Cambridge.

Fontenelle RO, Morais SM, Brito EH, Brilhante RS, Cordeiro RA, Nascimento NR, Kerntopf MR, Sidrim JJ, Rocha MF 2008. Antifungal activity of essential oils of Croton species from the Brazilian Caatinga biome. $J$ Appl Microbiol 104: 1383-1390.

Giang PM, Son PT, Hamada Y, Otsuka H 2005. Cytotoxic diterpenoids from Vietnamese medicinal plant Croton tonkinensis Gagnep. Chem Pharm Bull 53: 296-300.

Hiruma-Lima CA, Gracioso JS, Bighetti EJ, Grassi-Kassisse DM, Nunes DS, Brito AR 2002. Effect of essential oil obtained from Croton cajucara Benth. on gastric ulcer healing and protective factors of the gastric mucosa.
Phytomedicine 9: 523-529.

Holetz FB, Pessini GL, Sanches NR, Cortez G, Nakamura CV, Dias-Filho BP 2002. Screening of some plants used in the Brazilian folk medicine for the treatment of infectious diseases. Mem Inst Oswaldo Cruz 97: 10271031.

Kaneda N, Pezzuto JN, Soejarto DD, Kinghorm AD, Farnsworth NR, Santisuk T, Tuchinda P, Udchachon J, Reutrakul V 1991. Plant anticancer agents: XLVIII. New cytotoxic flavonoids from Muntingia calabura roots. J Nat Prod 54: 196-206.

Leal-cardoso JH, Fonteles MC. 1999. Pharmacological effects of essential oils of plants of the northeast of Brazil. An Acad Bras Cienc 71: 207-213.

Logarto PA, Silva YR, Guerra SI, Iglesias BL 2001. Comparative study of the assay of Artemia salina L. and the estimate of the medium lethal dose (LD50 value) in mice, to determine oral acute toxicity of plant extracts. Phytomedicine 8: 395-400.

Loguercio AP, Battistin A, Vargas AC, Henzel A, Witt NM 2005. Antibacterial activity of hydro-alcoholic extract leaves of jambolan (Syzygium cumini (L.) Skells). Cienc Rural 35: 371-376.

Marini-Bettolo R, Scarpati ML 1979. Alkaloids of Croton draconoids. Phytochemistry 18: 520-520.

Martins AP, Salgueiro LR, Goncalves MJ, Vila R, Tomi F, Adzet T, da Cunha AP, Canigueral S, Casanova J 2000. Antimicrobial activity and chemical composition of the bark oil of Croton stellulifer, an endemic species from S. Tome e Principe. Planta Med 66: 647-650.

Matos FJA 1988. Introdução a fitoquímica Experimental. Fortaleza, Ed. UFC, 126p.

McChesney JD, Clark AM, Silveira ER 1991. Antimicrobial diterpenes of Croton sonderianus, 1. Hardwickic and 3,4-secotrachylobanoic acids. J Nat Prod 54: 16251633.

Meyer BN, Ferrigni NR, Putnam JE, Jacobsen LB, Nichols DE, Maclaughlin JL 1982. Brine shrimp: a convenient general bioassay for active plant constituents. $J \mathrm{Med}$ Plant Res 45: 31-34.

Nakamura CV, Ueda-Nakamura T, Bando E, Melo FN, Cortez DG, Dias-Filho BP 1999. Antibacterial activity of Ocimum gratissimum L. essential oil. Mem Inst Oswaldo Cruz 94: 675- 678.

Nascimento GGF 2000. Antibacterial activity of plant extracts and phytochemicals on antibiotic-resistant bacteria. Braz J Microbiol 31: 247-256.

Nunes XP, Mesquita RF, Silva DA, Lira DP, Costa VCO, Silva MVB, Xavier AL, Diniz MFFM, Agra MF 2008. Constituintes químicos, avaliação das atividades citotóxica e antioxidante de Mimosa paraibana Barneby (Mimosaceae). Rev Bras Farmacogn 18 (Supl): 718-723.

Palmeira SF, Moura FS, Alves VL, Oliveira FM, Bento E, Conserva LM, Andrade EH 2003. Neutral components from hexane extracts of Croton sellowii. Flavour Frag J 19: 69-71.

Peres MTLP, Franco DM, Cruz AB, Pizzolatti MG, Yunes RA 1997. Chemical composition and antimicrobial activity of Croton urucurana Baillon (Euphorbiaceae). J Ethnopharmacol 56: 223-226.

Pott A, Pott VJ. 1994. Plantas do Pantanal, EMBRAPA, Corumbá, Brasil.

Rodriguez JA, Hiruma-Lima CA, Souza-Brito AR 2004. Antiulcer activity and subacute toxicity of transdehydrocrotonin from Croton cajucara. Hum Exp Toxicol 23: 455-461.

Siani AC, Ramos MFS, Menezes-de-Lima O, Soares ROA, 
Rosas EC, Susunaga GS, Guimarães AC, Zoghbi MGB, Henriques MGMO 1999. Evaluation of anti-inflamatory-related activity of essential oils from the leaves and resin of species of Protium. $J$ Ethnopharmacol 66: 57-69.

Silva TMS, Nascimento RJB, Batista MM, Agra MF, Camara CA 2007. Brine shrimp bioassay of some species of Solanum from Northestern Brazil. Rev Bras Farmacogn 17: 35-38.

Sousa FCF, Melo CTV, Citó MCO, Félix FHC, Vasconcelos SMM, Fonteles MMF, Barbosa-Filho JM, Viana GSB 2008. Plantas medicinais e seus constituintes bioativos: Uma revisão da bioatividade e potenciais benefícios nos distúrbios da ansiedade em modelos animais. Rev Bras Farmacogn 18: 642-654.

Suffredini IB, Sader HS, Gonçalves AG, Reis AO, Gales AC, Varella AD, Younes RN 2004. Screening of antibacterial extracts from plants native to the Brazilian Amazon Rain Forest and Atlantic Forest. Braz J Med Biol Res 37: 379-384.

Vieira RHSF, Rodrigues DP, Gonçalves FA. 2001. Microbicidal effect of medicinal plants extracts (Psidium guajava Linn. and Carica papaya Linn.) upon bacteria isolated from fish muscle and known to induce diarrhea in children. Rev Inst Med Trop 43: 145-148.

Volpato AMM, Rios EM, Miguel MD, Sander PC, Miguel OG 2001. Investigação da atividade antibacteriana de Calendula officinalis L. (Asteraceae). Rev Vis Acad 2: 7-10. 